Jolanta Walas-Trębacz, $\mathrm{PhD}^{1}$

The Cracow University of Economics, Poland
SCIENTIFIC REVIEW ARTICLE doi:10.5937/ekonomika1502039W

Received: March 8, 2015

Accepted: March 31, 2015

\title{
MANAGEMENT INSTRUMENTS USED FOR THE IMPROVEMENT OF THE ENTERPRISE VALUE CHAIN IN ORDER TO INCREASE ITS COMPETITIVENESS
}

\begin{abstract}
The aim of the article is to present stages realized in the process of improvement of the enterprise value chain and the characteristics of basic instruments used for searching directions to improve the efficiency of the enterprise value chain in order to increase its competitiveness in the market. The conducted analysis of the literature has allowed to explain the concept of the value chain. Furthermore, in the elaboration the scope of actions undertaken in the methodology to improve value chain was indicated and the classification of concepts and methods used for the improvement of the enterprise value chain was presented. The synthetic characteristics of selected management tools which can be used to improve the enterprise value chain, such as QFD method, value analysis, value stream mapping, ABC method, benchmarking, outsourcing, Lean Management, BSC, has a special position in the article.
\end{abstract}

Key words: value chain, $Q F D$, value analysis, value stream mapping, $A B C$, benchmarking, outsourcing, Lean Management, TQM, BSC

JEL classification: $D 2, L 1, L 6, M 2$

\section{КОРИШЋЕЊЕ ИНСТРУМЕНАТА МЕНАЏМЕНТА ЗА УНАПРЕЪЕЊЕ ЛАНЦА ВРЕДНОСТИ ПРЕДУЗЕЪА У ЦИЉУ ПОВЕһАЊА ЊИХОВЕ КОНКУРЕНТНОСТИ}

\begin{abstract}
Апстракт
Циь рада је да представи фазе реализоване у процесу унапређења ланца вредности предузећа и карактеристике основних инструмената који се користе за претражсивање упутства за побољшање ефикасности ланща вредности предузећа у цииьу повећана конкурентности на тржншту. Спроведена анализа литературе омогућила је објашњење конщепта ланца вредности. Осим тога, наведен је обим радюи предузетих у методологији побољшања ланща вредности и представљена је класификачија конщепата и метода за побољшање ланиа вредности предузећа. Синтетичке карактеристике одабраних менаимент алата који се могу користити за побољшање ланца вредности предузећа, као што су QFD метода, анализа вредности, streaт мапирање вредности, АBC метода, бенчмаркинг, аутсорсинг, Lean Management, BSC, имају посебно место у раду.
\end{abstract}

Кључне речи: ланаи вредности, QFD, анализа вредности, stream мапирање вредности, ABC, бенчмаркинг, аутсорсинг, Lean Management, TQM, BSC.

${ }^{1}$ walasj@uek.krakow.pl 


\section{Introduction}

Value based management that creates an enterprise organizational system consists in assessing the efficiency of their operation from the customers' perspective and executive possibilities appointed by the potential that the firm has.

Enterprises' openness to changes and the possibility of continuous adaptation of their activities to the environmental conditions requires perceiving and responding to customers' needs by creating new values for them. The value chain as one of the models showing the system of creating value in an enterprise allows to identify processes realized in the organization and to assess the effectiveness of achieving them due to determining and developing specific measures and methods of measuring the results of these processes.

The value chain is a tool for identifying the way how to create more value for the customer, and thus for the enterprise. It is an essential tool for identifying and assessing each link (process) that influences on the creating value process.

\section{The concept of enterprise value chain}

The value chain is one of the important concepts showing the process of "adding" value to the product. In the literature, it is defined variously, but it can be seen that a key issue in each of interpretation is the emphasis on creating value added (for the customer), which is the consequence of the implementation of ordered processes with one another. Table 1 presents the chosen definitions of the value chain.

Table 1: Interpretation of the concept of "value chain"

\begin{tabular}{|l|l|}
\hline \multicolumn{1}{|c|}{ Author } & \multicolumn{1}{c|}{ Definition of the value chain } \\
\hline P. Drucker & $\begin{array}{l}\text { It is an ordered sequence of different types of functions (activities), generating value of } \\
\text { the product, which is determined by market relations between the enterprise and the buyer. }\end{array}$ \\
\hline M.E. Porter & $\begin{array}{l}\text { This is strictly defined stream of different types of activities that are undertaken by enterprises } \\
\text { forming in different way a common system of values. }\end{array}$ \\
\hline J. Rokita & $\begin{array}{l}\text { This is a sequence of interrelated activities carried out within the manufacturing process of } \\
\text { the final product or service, giving the possibility to achieve value added. }\end{array}$ \\
\hline A. Stabryła & $\begin{array}{l}\text { It is a sequence of interrelated (serial or parallel) phases of the management process and } \\
\text { executive process referred to the particular sector of the enterprise's activity. }\end{array}$ \\
\hline $\begin{array}{l}\text { P.B. Schary, } \\
\text { T. Skjott- }\end{array}$ & $\begin{array}{l}\text { It consists of one integral system, in which processes leading to the formation of the product are } \\
\text { realized, and each process is assessed from the point of view of its contribution to the total value added } \\
\text { generated by the chain. }\end{array}$ \\
\hline
\end{tabular}

Source: own elaboration based on: (Drucker, 1976, p. 120; Rokita, 2005, p. 196; Porter, 2006, p. 58; Stabryła, 2007, p. 165; Schary, Skjott-Larsen, 2002, p. 14).

The value chain is a concept constructed on the basis of system approach to management. It consists of two parts: structural and methodical one. The first one contains a model of the enterprise as a system of activities, describes its components and the relationship between them. The second one provides indications for analysis - costs of activities and sources of differentiation (Czakon, 2003, p. 33). The aim of the entire value chain is to create in an effective and flexible manner the highest value added, which will be accepted by the final customer. 
The value chain might be considered in broader context, which takes into account its three levels: the level of the economic path of the sector, the level of the enterprise value chain in cross-section of processes, and the level of activities (Nita, 2008, p. 78).

In the enterprise value chain a number of important changes caused by both external factors, and internal ones have occurred. To the factors that have a significant impact on the structure of the value chain are included: decomposition, specialization, delocalisation, configuration, integration, externalization, globalization, cooperation, virtualization, recombination, coordination (Aurik, Jonk, Willen, 2003, p. 12). Widely used IT systems, new ways of communicating and managing borderless activities of the corporation have a particular importance for the transformation of chains of enterprise value added.

\section{Stages of improvement of the enterprise value chain}

Nowadays, the improvement of the process of creating enterprise value chain in variable operating conditions is becoming an important challenge to the entire organization. It is based on a constant searching possibilities to improve daily operations of realized processes as well as the relationship between the processes. This need is caused by constant cost competition, and also pressure to increase widely understood quality. Improvement of processes is emphasized in various management concepts and methods including, inter alia, the Kaizen philosophy, quality management, logistics or knowledge management.

The method of improving the enterprise value chain in diagnostic terms includes the following phases of conduct:

1. Determination of aim to improve system of the enterprise value chain.

2. Identification of criteria used to assess the value chain model.

3. Determination of type of enterprise value chain model and its assessment.

4. Development of options to improve the existing enterprise value chain according to the adopted model of the value chain.

5. Selection of the final variant of the value chain (using the evaluation criteria) and the development of detailed project of the improved value chain model.

6. Implementation and assessment of effectiveness of improved model of value chain.

An important task in the process of improving the enterprise value chain is to determine the structure of the value chain for the entire sector, that is recognition of activity of creating an economic path connected with producing a particular product (Gierszewska, Romanowska, 2003, p. 184). The basis for achieving a competitive advantage is to understand the entire sector, in which the enterprise competes, not just that part of the value system in which it participates. The possibility to deliver greater value added to the value chain depends on skills of understanding its determinants by each link and considering them in global value chain strategy (Kasiewicz, 2005, p. 24).

Apart from the subjective structure of the entire value chain, a substantial research issue is an analysis of processes of integrating all links, i.e. determination of objective structure, whereby the transfer takes place: material, financial, information, and knowledge one.

The designed value chain must respond to market demand in a manner compatible with the strategy of the enterprise. The enterprise strategy which is adopted by it must go out from customers' needs, which provide services or will provide services to them. Depending on customers' needs, the value chain in the enterprise must provide an appropriate compro- 
mise between speed of reaction and efficiency. The enterprise, which value chain enables to meet customers' needs effectively, gains higher market share compared to the competitors, and its activity becomes more profitable.

\section{Classification of concepts and methods used to improve the enterprise value chain}

Depending on adopted aim to improve the enterprise value chain, there can be distinguished two approaches: a) Approach in which used methods lead to radical (revolutionary) changes in the value chain: e.g. Process Innovation, Business Process Reengineering, Business Process Redesign, Simultaneous Engineering, Time Compression Management, Fast Cycle Response, Big Picture Improvement, etc.; b) Approach in which used methods allow gradual changes in improvement of the value chain: e.g. Process Value Analysis, Overhead Value Analysis, Activity Value Analysis, Business Process Improvement, Total Quality Management, Activity-based-costing, Lean Management, Outsourcing, Benchmarking, Just-in-time, Balance Scorecard, etc.

Different concepts and methods are used in the improvement of the value chain that can be classified using the selected groups of methods presented in Table 2.

Table 2: Classification of selected methods used to improve the value chain

\begin{tabular}{|c|}
\hline Economic and financial methods \\
\hline $\begin{array}{l}\text { Ratio analysis, cost analysis, budgeting, analysis of results, data analysis, comparison method, value } \\
\text { stream maps, ABC method, reporting system, controlling, analysis of financial statements }\end{array}$ \\
\hline Management methods \\
\hline $\begin{array}{l}\text { Lean management, management by objectives, management by results, BSC, outsourcing, risk } \\
\text { management, TQM, controlling, time management, JIT, team management, TBM }\end{array}$ \\
\hline Behavioral methods \\
\hline $\begin{array}{l}\text { Observations, analysis of documentation, interviews, face-to-face conversations, training, communication } \\
\text { methods, opinion poll, surveys, questionnaires, tests }\end{array}$ \\
\hline Methods of strategic analysis \\
\hline $\begin{array}{l}\text { Analysis of key success factors, resource analysis, stakeholder analysis, benchmarking, Porter five forces } \\
\text { analysis, BSC, SWOT analysis, strategic balance }\end{array}$ \\
\hline IT methods \\
\hline Database, monitoring, MRP, ERP, CRM, simulation methods, modelling methods \\
\hline Heuristic methods \\
\hline Delphi method, brainstorming, method of analogy, morphological method, expert method \\
\hline Operational research methods \\
\hline Decision tree, programming (linear, dynamic), fault tree analysis, decision matrix, forecasts \\
\hline Qualitative methods \\
\hline QFD, FMEA, TQM, statistical quality control, Ishikawa diagram \\
\hline Organizational methods \\
\hline $\begin{array}{l}\text { Value analysis, schedules, network techniques, diagrams, procedures, plans, charts, description methods of } \\
\text { the organizational structure, methods of analysis and improvement of processes, checklists }\end{array}$ \\
\hline $\begin{array}{l}\text { Marketing methods } \\
\text { Market research, customer needs analysis, competitive analysis }\end{array}$ \\
\hline Statistical methods \\
\hline Trend extrapolation, multivariate analysis, analysis of preferences, scalin \\
\hline
\end{tabular}

Source: Walas-Trębacz, 2015, p. 448 
Further development of methods used to improve the value chain will require use of IT systems, which largely accelerate the analysis of previously collected data, comparing them over a period of time, allows to create different models and simulations, which save the resources and time for their traditional constructing.

\section{The characteristics of selected concepts and methods used to improve the enterprise value chain}

In synthetic manner, there are presented possibilities of using the selected concepts and methods to improve the value chain, such as: QFD, value analysis, value stream mapping, activity based costing, benchmarking, outsourcing, Lean Management, TQM, BSC.

A very useful method in the analysis and improvement of value chain serving customers' needs and preferences, and designing a new product is Quality Function Deployment. The method came into existence in Japan in the 1960s of the Twentieth Century. Yoji Akao is generally believed as its creator, who introduced it in Mitsubishi Kobe shipyard in 1972 (Akao, 1972, p. 7-14). Then, the method was used in the 80 s by American companies like Ford and Xerox, and later by companies, such as: Digital Equipment, Hawlett-Packard, AT\&T, ITT (Hauser, Clausing, 1988, p. 67-68). This method is used to transform customer's requirements into conditions, which the enterprise must meet during the consecutive stages of manufacturing and delivering products, starting with design, through procurement, production and distribution, through to sales and service (Hamrol, Mantura 2004, p. 229). The purpose is to reposition customer's needs (internal and external) to the characteristics of the product, processes and resources in the value chain. It is used in the process of transferring values into strategic and operational decisions of implemented operations in the value chain (Lowe, Ridgway, 2000, p. 13). The QFD method is applicable both for products and services (Obora 2000, p. 112).

By using the QFD method the enterprise can achieve the benefits of various kinds, inter alia:

- Organization (inter alia: shortening the stage of product design; reducing the number of changes in product and process design; reducing changes in a project; identifying weaknesses of process and product, etc.);

- Economic (inter alia: reduces the cost of design changes; reduces the cost of inspections and product quality control; reduces the cost of presence of manufacturing defects, etc.);

- Sociopsychological: for the enterprise (inter alia: improves communication within the enterprise, enables integration of employees, breaks the divisions between various organizational units, identifies areas of competitive advantage), and for the customer (inter alia: focuses product on customer's needs, simplifies the identification of customer's needs, improves communication between customer and the enterprise, increases customer satisfaction of obtaining product).

The QFD method becomes a popular tool in various industries because it has a high use and cognitive value, but requires high knowledge, experience and ingenuity in creating process as well as links to casual analysis.

An important method used in the research and assessment of creating value of the product is Value Analysis. L. D. Miles is considered to be the founder of value analysis who 
developed and implemented it in 1947 (Miles, 1972). The task of value analysis defined by L. D. Miles is to establish such a multifunctional relationship between product and customer which will meet satisfactorily all the functions required by the customer at the relatively lowest cost (Martyniak, 1997, p. 105). This method can be used to test produced or designed product, manufacturing processes, administrative and office works. The basis of value analysis is to identify the function of the product (referred as the ability to achieve the target result), and then examine possible options for obtaining these functions, and select such a way of manufacturing and delivering a product which causes the highest value of the effect/cost index. The purposes of analysis and shaping values are achieved through: improving customer satisfaction resulting from the product quality; raising the level of customer service and benefits derived from the product; influencing by various methods on reduction of products costs in the value chain; increasing efficiency of activities; improving efficiency of material flow; using resources efficiently; increasing the profitability of particular products and groups of products, customers, markets and distribution channels (Śliwczyński, 2011, p. 196). The value analysis in the value chain might be applied to product value analysis and process value analysis. The analysis allows to assess the extent to which product or process meets customer needs.

Nowadays, the VA method is still used. In recent years, can be seen more frequent reaching for it in the metal, chemical, computer, IT, transport and other industries (Morgan, 2003, p. 41). The usefulness of VA method largely depend on the results of casual analysis, staff experience, appropriateness of chosen, analyzed factors affecting the value chain and operations in it. Value analysis despite its high usefulness is a labour-intensive and costly method requiring many objective measurements and analysis as well as creative thinking in shaping solutions (Wawak, 2012).

Another method helpful in improving the value chain is Value Stream Mapping. The creators of value stream mapping are Taiichi Ohno and Shigeo Shingo who worked for Toyota plants in 1980. At the beginning, a method used to eliminate losses in the production process in order to achieve competitive advantage was called Material and Information Flow Mapping. To popularization of value stream mapping method contributed M. Rother and J. Shook (1999). The VSM method helps to see and understand the property, financial and information flows properly in the value chain (Czerska, 2009, p. 18). This is an instrument used to analyze all stages of property flow. It is useful in correlating process and assessing the impact of processes on the value of the final product during its manufacturing and delivery. Value stream mapping helps to identify critical processes whose realization has a significant impact on the results of activities of the entire enterprise. Value stream mapping also allows to identify actions not adding any value (inter alia waste and overproduction, correcting errors, irrational transport, surplus of stocks, queue and waiting period) and directs managers to take action "slimming" and correcting processes (Rother, Shook, 1999, p. 23-25).

The VSM method stacks up both in manufacturing enterprises where product's path is followed (from raw material to finished product), and in service enterprises (from the beginning to the end of execution of the contract), what means that it can be used in all organizations. It is a method that neither requires to increase the costs of computer software used to analysis, special equipment nor specific staff qualifications. At the same time, this method is effective (Rother, Shook, 1999, p. 28). However, capturing all necessary information in more complex cases is difficult by using the VSM method. Therefore, elaboration of value stream mapping is labour-intensive, requires a lot of experience but it is a functional and effective 
tool to assist management in making decisions concerning changes in the value chain. It is believed that the mapping will develop based on the use of IT systems that will support their creation and analysis.

The basic tool from the groups of methods used to analyze costs in the value chain is Activity-Based-Costing. This method is used to identify and settle costs in the enterprise during the implementation of the processes in the value chain. The concept of activity based costing was established in response to criticism of traditional methods of cost accounting which in changing conditions of functioning of the organization are no longer sufficient for making management decisions. It was developed in the late 1980s of the Twentieth Century in the United States, and its creators were R. Cooper and R. Kaplan (Cooper, 1988; Kaplan, Cooper, 2002). The basic assumptions of the concept say that the organization's resources are consumed by activities (processes) rather than products or organizational units, and the fundamental part of overheads and indirect costs does not depend on the volume of products, but varies according to the intensity of their activities (processes). Activity based costing requires perspective looking at organization, requires the identification of processes at the various levels of specificity, it is possible for practical use if business processes are known. The most important steps in cost management activities include: identification of specific actions constituting a specific process; construction of measures referred to the distinguished actions; determination of thcosts of each undertaken action and "valuation" of the entire sequence on the basis of costs of single actions constituting its composition (Błoński, Kondracki, 2004, p. 15).

In the majority of value chains every action has a distinct cost structure that is determined by various cost drivers. Cost analysis therefore requires breaking down the enterprise value chain in order to identify: the relative importance of each action in relation to the total cost of the product, cost drivers for each activity, and the relative efficiency with which the enterprise carries out each process, the impact of the cost of one process to the costs of the another (the links between processes), and activities which should be carried out on enterprise own and those which should be outsourced to get opportunities to reduce costs (Grant, 2011, p. 303-304). The primary task of ABC method is to identify diversified levels of cost absorption resulting from portfolio of a number of products with different supply operations, production and distribution adapted to different requirements of customers (Kaplan, Atkinson 1998, p. 20). Operating costs are assigned to products on the basis of level of activity absorption by the product. The total cost of the product is obtained by summing direct and indirect costs. Thus, the $\mathrm{ABC}$ method allows to change the ratio between direct and indirect costs, capture and eventually resign or improve those activities that are inefficient. In cost accounting process approach, in which activities charge the product in direct proportion to their size and resource consumption for the benefit of products, is used.

Although, the ABC method is an effective and valuable method for the enterprise (allows to determine real costs of product, particular processes, analyze the profitability of activities, eliminate activities not constituting a value, optimize and rebuild processes, determine a reasonable level of resource utilization, identify cost drivers of processes and their influence on activities), it is not widely used because of its high labor-intensity, cost-absorption, difficulty in making accurate measurements and conducting detailed record of costs incurred in the enterprise without taking into account the process approach. Tools used to support the ABC method include: using IT solutions, budgeting, controlling, ratio analysis, process analysis.

Another helpful method, which is used in many stages of the value chain improvement, inter alia: in the assessment of resources capability and enterprises competencies, in the 
assessment and improvement of processes and products, in the assessment of costs incurred for the realization of specific processes or products is benchmarking. Benchmarking inspires to seek new solutions and learn from the best.

The undisputed contribution to the development of benchmarking has Rank Xerox Corporation, which in 1979 took action considered to be the first comparative analysis in the United States. The one option of benchmarking, which is applied in practice, is product benchmarking or process benchmarking. The application of this method with respect to products and processes might significantly affect enhancement of the efficiency of the organization, but it requires many visits in other enterprises, it is time-consuming, it is associated with incurring high costs, and requires obtaining difficult to access information from many sources (Karlof, Ostblom, 1995, p. 60-61). In comparison to benchmarks which consist only of outcome parameters, process benchmarking allows to know the effects of activities of various factors on the organization whose processes are considered to be standard (Zabawa, Krawczyk, 2006, p. 30-34; Bogan, English, 2006, p. 128). This is due to the fact that processes are a universal category and when they are the subject of benchmarking the individual conditions may affect to a lesser extent the results of the comparative analysis and the effectiveness of conducted benchmarking (Tolosi, Lajtha, 2000 , p. 347). Improving organization's processes can also be achieved by a constant, continuous implementation of ideas from other organizations. If there is a constant exchange of ideas between the benchmarking partners, it is possible to obtain continuous improvement for all participants in the process of benchmarking (Mustafa Pulat, 1994, p. 40). Benchmarking is very usefull for effective process management in the process-oriented enterprises, which is created by "transformation of functional organization structure into the process model of organizational structure" (Krstić, Jovanović, Kahrović, 2012, p. 370).

The use of benchmarking in practice is not an easy task because for example, the selection of processes as the object of benchmarking analysis requires knowledge of their progress and assessment of their impact on the performance of the organization. Benchmarking is a tool used regardless of the industry or a type of business, but it is necessary to select various operational measures used to comparisons between different business processes. However, R. Mc Adam believes that benchmarking substantially contributed to the development of the organization being a factor causing change of the approach: from a simplified process approach (referred as "function-process" to "process") to more comprehensive network process approach (referred as "network-process") (Mc Adam, 2001, p. 332). This approach also has changed with the beginning of perception of the value chain as a continuous indivisible process, which converts faults into required products by using resources (Hewitt, Robinson, Bennett, 1996, p. 8-14).

The next management concept used to reduce costs and increase the flexibility of the enterprise value chain is outsourcing. While the history of outsourcing as a phenomenon is long, increasing use of it in current economies and enterprises has been observed since the last three decades. For the first time, outsourcing became popular in the early 1980s of the Twentieth Century when started to pay attention to the growing importance of outsourcing of manufacturing processes, and enterprises decided to fragment these processes and outsource intermediaries, subgroups and components to sub-suppliers more and more often. The result of that was a growing fragmentation of the value chain and closer links between cooperating manufacturing enterprises located in different parts of the world. 
The real revolution in outsourcing was in the 1990s of the Twentieth Century (Ciesielska, Radło (red.), 2011, p. 13-14). Over time, outsourcing has begun to include not only production processes, but also logistics, storage, IT services, accounting services, customer service, R\&D and the others. Searching for economic efficiency means transformation for the enterprise, whereupon it performs only this what is able to perform better than others and coordinates the activities carried out by external entities with own value chain (Czakon, 2005, p. 57). Thus, considering outsourcing of components of the enterprise value chain in the context of the value system, it is a strategic decision, the choice of the scope of enterprise activity against a background of the manufacturing process of a complex product, or creating the product value chain (Trocki, 2001, p. 7-9). This decision allows to build core competencies, strategic assets, and constitutes an important element in shaping the enterprise opportunities or creating its competitive advantage in the market. Outsourcing as a management concept has a situational character because it takes into account most of the determinants of a particular enterprise and the value system in which it operates. At the beginning, the main motive of outsourcing were costs. Over time, there has been the evolution of this approach, and enterprises, which were applying it, have tried to gain a competitive advantage by combining elements of low costs, differentiation, concentration, and low price as well as using the opportunities arising from access to new resources and skills occurring in other enterprises, increasing flexibility and rapidity of activities, improving enterprise activities or reducing risk (Ciesielska, Radło (red.), 2011, p. 24). Outsourcing in comparison to fee-for-task agreement, allows to create a special kind of relationship between enterprises, or such a partnership which affects the functioning of the whole enterprise, in pursuance of long-term cooperation under which the third party takes over the task to rationalize the level of costs incurred by the enterprises commissioning the service, and at the same time aims to secure the proper level of service quality (Nogalski, 2010, p. 283). Outsourcing is also a strategy that allows to increase effects of synergy associated with the implementation of mergers and acquisitions of enterprises. In its extreme form, outsourcing can lead to create virtual enterprises, where most of value chain processes are commissioned to.

It also should be mentioned that the use of outsourcing in the enterprise is not always easy, because wrong: planning, implementation and enforcement of outsourcing projects and the terms of the agreement with external partners can lead to negative consequences for the enterprise which decrease the flexibility and efficiency, and increase its operating costs. The most frequently mentioned risks arising from the improper use of the concept of outsourcing in enterprises are: strategic risks (e.g. getting rid of competencies, increasing dependence on suppliers, possibilities of losing sources of competitive advantage, accepting cultural differences); financial risks (e.g. increasing variable costs, not reaching the intended savings); personal and legal risks (e.g. possibilities of transferring skills of workers from other forms and lack of having own staff, difficulties in transferring licenses, possibilities of losing know-how, weakening of its own employees motivation); organizational and operational risks (e.g. reducing the flexibility of outsourced management functions and control over an outsourced activity, possibilities of losing confidential information, reducing speed of completing services and changing the characteristics of external services) (Niemczyk, 2006, p. 142).

Helpful management concept used in improving the value chain and at the same time raising the competitiveness of the enterprise is lean management. This term is translated as "slimming" management and replaced by a broader formulation - Lean Thinking or nar- 
rower term - Lean Production (Zimniewicz, 1999, p. 61). The lineage of this concept dates back to 1978 , or the history of the formation of the management system in the Japanese car company Toyota. E. Toyota and T. Ohno are considered for its precursors (Nogalski, 2010, p. 300). In contrast, a breakthrough in the development of this concept falls on the year 1991, when the results of the analysis and assessment of the situation in the global automotive industry (Japan, the United States and Western Europe) were published (Bartusik, 2000 , p. 95). Lean Management consists in reducing significantly the cost of value added production for the customer by reducing employment, production space, finances involved in the production, capital expenditures, time, etc. The LM method comes down to reducing the scope of internal functions of the enterprise to strictly necessary activities (Błoński, Kondracki (ed.), 2004, p. 63). This concept emphasizes the need to eliminate waste in all aspects of functioning of the enterprise and uses such form of organization to continually increase the effectiveness and efficiency of the enterprise. Lean Management allows for the implementation of interconnected goals of the enterprise which are significant from the point of view of the effectiveness of value chain management, namely: focusing on customers' needs and values supplied to them, short production cycle, high integration of production process, timeliness of delivery, partnership with suppliers, continual improvement of quality, permanent improvement of processes and organizations, identification of employees with the objectives of the enterprise, maintaining minimum stocks, maximum utilization of production capacity, accelerating development of new products and introducing them in the market (Stadelmann, Lux, 1995, p. 33). The enterprise should engage in activities that bring value to it (Błoński, Kondracki (ed.), 2004, p. 63). The LM method defines value stream as a sequence of all necessary activities to design, lead to the order and delivery of a specific product to the customer. The value stream corresponds to the value chain and its analysis aims at extracting activities: creating value, supporting the creation of value, and not creating value (Czakon, 2005, p. 54). Lean Management provides transition criteria from the enterprise in a given form to the enterprise identical to the value chain (Womack, Jones, 1994, p. 93; Levy, 1997, p. 94-102). The implementation of this concept in the enterprise leads to a higher level of economic efficiency, quality and flexibility by finding and applying innovative solutions. However, to achieve the above results the enterprise is required to create a modern, participatory, pro-quality and pro-effective organizational culture (Nogalski, 2010, p. 304) and fulfil certain conditions, inter alia: the need to understand the essence of the concept of lean management by all employees, develop and implement strategies, tactics, and many management tools, upgrade skills of workers and managers, ensure employee participation in management, ensure proper working conditions, access to information, ability to avoid conflicts and remove their sources, and provide creativity and readiness for creative work on every worksite (Lichtarski (red.), 1997, p. 229). An important feature of the LM method is primarily a long-term and consistent implementation of selected management tools and techniques.

An important management concept used in the value chain is Total Quality Management. It means complete and continuous serving needs of the recipient who receives the highest value of the purchased good for a specified price. This is achieved at the lowest cost due to the best liberation of the potential possibilities of the enterprise (Błoński, Kondracki (red.), 2004, p. 78). TQM is a system of activities aimed at achieving customer satisfaction, commitment among employees, revenue growth and cost reductions (Strumiłło, 2010, p. 148). W.E. Deming is considered to be the classic of TQM concept. 
Comprehensive quality requires delegating responsibility to the lowest level of the organization, or involving all employees of the enterprise. The enterprise, which implements TQM, shows that the canon of TQM is to follow some set of rules that relate to, inter alia: enterprise orientation on results, customer orientation, leadership, process management, development and commitment of human resources, continuous learning, innovation and improvement to maximize the performance of an organization, development of partnership, system approach to management, decision-making based on facts, mutually beneficial relationships with suppliers, bearing social responsibility, etc. (Czakon, 2005, p. 50-51).

TQM as a constantly evolving management system consists of three components: values, tools and techniques, which aims to increase satisfaction of internal and external customers, connected with decreasing resource consumption (Hellsten, Klefsjo, 2000, p. 241). The application of TQM, as a matter of fact, is a special way to involve all employees in the functioning of the organization, getting active cooperation to implement enterprise strategy, and creating such an organization, where everyone works together harmoniously and does not compete with each other. TQM is defined as a universal method for improving the efficiency of teams, changing the way of thinking. TQM is gradually becoming a standard. The new edition of ISO 9000 contains many elements of TQM. The implementation of TQM takes several years and leaders of enterprise are required to adopt an attitude of teachers in relation to their employees. TQM is broadening knowledge constantly about what we do, how we do it and how can we improve it (Strumiłlo, 2010, p. 150-151).

The impact of TQM on the functioning of the value chain is evinced in its various dimensions, and the most important four components include: architecture and integration (e.g. designing value chain, developing relationships in the environment, process management), maneuvering (e.g. using decision support systems, service provider management, constantly improving processes and outcomes), information and communication (e.g. using integrated IT management systems, using common databases, using automatic identification in the form of a barcode), resource sharing (e.g. transport, storage, information and knowledge, IT systems, etc.) (Szymonik (red.), 2013, p. 145-146).

Enterprises (and especially management) that want to implement this concept need to "mature" to the philosophy of TQM. Too early and unprepared introduction of the concept may encounter many barriers sticked in the system as well as among people, inter alia sticked in: the budgetary conditions set by the quality, political conditions, arrogance, lack of knowledge, research, education, belief in its powers and competencies, autocratic behaviors) (Dew, 2003, p. 59-65).

A common method of measuring in the value chain management is Balanced Scorecard. It was constructed by R.S. Kaplan and D.P. Norton in 1992 (Kaplan, Norton, 1992, p.71-79). In their approach, the authors have taken into account four perspectives: financial, customer, internal processes, and innovation and growth opportunities. This method is often used to evaluate the activities of the entire enterprise at a strategic level, but due to its universal formula, it is used very easily in the management of the enterprise value chain. There can be offered many individual measures and indicators for each process in each area, not only within the enterprise, but also connected with external processes of the enterprise. It is a tool that should be seen as an integrated assessing system of value chain management from the strategic perspective and with the elements of operational 
management. It allows to answer to four basic questions: how customers see the enterprise, how efficient are internal processes in the value chain, whether the developed solutions are innovative and enable further growth and create value in the future, as well as how owners perceive the enterprise (Tarasiewicz, 2014, p. 97-98). It is important to link the designated measures and indicators with specific goals and tasks in different areas and at different levels of the enterprise, what allows to organize cause-effect relations between strategic objectives. Application of this method gives the possibility to look at the value chain from a broad perspective taking into account financial and non-financial aspects as well as from strategic and operational level. However, the use of BSC in the value chain management requires moving beyond traditional frames of cards (with four prospects) and taking into account the perspective of partnership which reflects the effects of interorganizational cooperation in the chain where the company participates. Measurement of effectiveness of the processes realized in the value chain through this method gives information about the level of implementation of the strategy of the whole chain and enables the identification of so-called "bottlenecks", or areas where might occur decrease of efficiency of processes which are carried out in the chain (Brzóska and others, 2012, p. 147-148).

There also should be indicated the limitations of this method compared to the value chain management, namely: during its implementation may occur problems associated with selecting adequate measures and indicators, and adapting them to the changes taking place in the enterprise; used and selected measures and indicators do not always allow to measure effectively integrated value chains including all of its partners, its application does not allow to measure and compare with competitors (the lack of this perspective) (Hazell, Morrow, 1992, p. 44-45), does not allow to assess the level of risk management in the value chain.

\section{Conclusion}

Nowadays, there is seen trend of shaping the organization where an analysis of key processes is conducted, the effects of the implementation of the basic processes are assessed, what undoubtedly fosters the implementation of the different methods and management concepts preferring a process approach, such as: TQM, lean management, outsourcing, JiT, kaizen, benchmarking, $\mathrm{ABC}, \mathrm{ABM}$ or $\mathrm{BSC}$. It should be expected more and more interest in implementing these instruments due to the numerous researches confirming achieving the great advantages by these enterprises that have wished to use them. These activities are undertaken mostly by large enterprises but they can be founded also in the SME sector. Cooperation or competition with corporations will enforce these enterprises to use an approach aimed at continuously improving its value chain. Searching for new sources of competitive advantage in the value chain is not only important for the enterprises that use competitive strategy but also for these ones which want to use them as a bargaining card in creating alliances or making mergers and acquisitions.

The purpose of the proper selection of structures and methods of process management and resource management in the value chain is their focus on value. Development and improvement of the value chain management model allow to better link the adopted assumptions of enterprise strategy with various processes occurring in the enterprise and give the possibility of more effective management, reducing costs and improving the efficiency of particular participants of the value chain and also of the entire value chain. 


\section{References}

Akao, Y. (1972). New Product Development and Quality Assurance - Quality Deployment System. Standarization and Quality Control, 25 (4), pp. 9-14.

Aurik, J, Jonk, G. \& Willen, R. (2003). Rebuilding the Corporate Genome. Unlocking the real Value of Your Business. John Wiley \& Sons, New Jersey.

Bartusik, K. (2000). Lean Management - współczesna koncepcja zarządzania przedsiębiorstwa. Zeszyty Naukowe Uniwersytetu Ekonomicznego w Krakowie, Kraków, No. 544, pp. 95-106.

Błoński, M. \& Kondracki, K. (red.) (2004). Zarządzanie na przełomie wieków. Hays Personnel, Warszawa.

Bogan, Ch.E. \& English M.J. (2006). Benchmarking jako klucz do najlepszych praktyk: wykorzystuj pomysty najlepszych firm. Helion, Gliwice.

Brzóska, J., Karbownik, A., Kruczek, M., Szmal, A. \& Żebrucki, Z. (2012). Strategiczna karta wyników w teorii i praktyce. Wyd. Politechniki Śląskiej, Gliwice.

Ciesielska, D. \& Radło, M.J. (red.) (2011). Outsourcing w praktyce. Poltext, Warszawa.

Cooper, R. (1988). The rise of activity-based costing - part two: what is an activity-based system. Journal of Cost Management, 2 (2), pp. 41-48.

Czakon, W. (2003). Operacyjne rozwinięcia koncepcji łańcucha wartości. Przegląd Organizacji, 9 , s. $30-33$.

Czakon ,W. (2005). Łańcuch wartości w teorii zarządzania przedsiębiorstwem. Prace Naukowe Akademii Ekonomicznej w Katowicach, Katowice.

Czerska, J. (2009). Doskonalenie strumienia wartości. Difin, Warszawa.

De Vita, G. \& Wang. C.L. (2006). Development of Outsourcing Theory and Practice: A Taxonomy of Outsourcing Generations [w:] W. Kehal, V.P. Singh, Outsourcing and Offshoring in the XXIst Century: A Socio-economic Perspective. Idea Group Publishing, London.

Dew, J. (2003). The seven deadly sins of quality management. Quality Progress, 36(9), pp. 59-65.

Drucker, P. (1976). Skuteczne zarządzanie. Zadania ekonomiczne a decyzje zwiąane z ryzykiem. Wydawnictwo PWN, Warszawa.

Gierszewska, G. \& Romanowska, M. (2003). Analiza strategiczna przedsiębiorstwa. PWE, Warszawa.

Grant, R.M. (2011). Współczesna analiza strategii, Oficyna a Wolters Kluwer business. Warszawa.

Hamrol, A. \& Mantura, W. (2004). Zarządzanie jakością. Teoria i praktyka, WN PWN, Warszawa.

Hauser, J. \& Clausing, D. (1988). House of Quality, Harvard Business Review, May-June, pp. 3-13.

Hazell, M. \& Morrow M. (1992). Performance measurement and benchmarking. Management Accounting, 70 (11), pp. 44-45. 
Hellsten, U. \& Klefsjo, B. (2000). TQM as a Management System Consisting of Values, Techniques and Tools. The TQM Magazine, 12(4), pp. 238-244.

Hewitt, F., Robinson, S. \& Bennett, D. (1996). Modelling and benchmarking business process: the supply-line example. Benchmarking for Quality Management \& Technology, 3 (2), pp. 4-14.

Kaplan, R.S. \& Norton, D.P. (1992). The Balanced Scorecard - measures that drive performance. Harvard Business Review, 70 (1), pp. 71-79.

Kaplan, R.S. \& Atkinson, A.A. (1998). Advanced Management Accounting. PrenticeHall, New Jersey.

Kaplan, R.S. \& Cooper, R. (2002). Zarządzanie kosztami i efektywnością. Oficyna Ekonomiczna, Kraków.

Kasiewicz, Z. (2005). Badanie wartości firmy w zarządzaniu operacyjnym. Wydawnictwo SGH, Warszawa.

Karloef, R.S. \& Oestblom D.P. (1995). Benchmarking, równaj do najlepszych. Biblioteka Menedżera i Bankowca, Warszawa.

Krstić, B., Jovanović, S., \& Kahrović, E., (2012). Process-oriented enterprise management as a determinant of organizational behavior in contemporary business terms, Actual Problems of Economics, 11 (137), pp. 369-380.

Levy, D.L. (1997). Lean Production in an International Supply Chain. Sloan Management Review, 38, pp. 94-102.

Lichtarski, J. (red.) (1997). Podstawy nauki o przedsiębiorstwie. Wydawnictwo Akademii Ekonomicznej we Wrocławiu, Wrocław.

Lowe, A.J. \& Ridgway, K. (2000). Quality Function Deployment. University of Sheffield, Sheffield.

Martyniak, Z. (1997). Organizacja i zarzadzanie. 15 efektywnych metod. Antykwa, Kraków-Kluczbork.

Mc Adam, R. (2001). Fragmenting the function-process interface, The role of process benchmarking. Benchmarking: An International Journal, 8 (4), pp. 332-348.

Miles, L.D. (1972). Techniques of Value Analysis and Engineering. McGraw-Hill, New York.

Morgan, J. (2003). Value Analysis makes a comeback. Purchasing Magazine on line, 20 November.

Mustafa Pulat, B. (1994). Process Improvements through Benchmarking. The TQM Magazine, 6 (2), pp. 37- 40.

Nita, B. (2008). Rachunkowość w zarządzaniu strategicznym przedsiębiorstwem. Oficyna Wolters Kluwer, Kraków.

Niemczyk, J. (2006). Wyróżniki, budowa i zachowania strategiczne układów outsourcingowych. Wydawnictwo Akademii Ekonomicznej we Wrocławiu, Wrocław.

Nogalski, B. (2010). Lean Management, [w:] Koncepcje zarzadzania, M. Czerska, A. Szpitter (red.). C.H. Beck, Warszawa.

Obora, H. (2000). QFD - metoda zaawansowanego planowania jakości, ZN AE, Kraków, No. 534. 
Porter, M.E. (2006). Przewaga konkurencyjna. Osiaganie i utrzymanie lepszych wyników. Wydawnictwo Helion, Gliwice.

Rokita, J. (2005). Zarzadzanie strategiczne, tworzenie przewagi konkurencyjnej. PWE, Warszawa.

Rother M. \& Shook J. (1999). Learning to see-value stream mapping to create value and eliminate mud. The Lean Enterprise Institute, Massachusetts.

Schary, P.B. \& Skjott-Larsen, T. (2002). Zarządzanie globalnym łańcuchem podaży. WN PWN, Warszawa.

Stabryła, A. (2007). Zarządzanie strategiczne $w$ teorii i praktyce firmy. WN PWN, Warszawa-Kraków.

Stadelmann, M. \& Lux W. (1995). Hot Topics oder kalter Kaffee? Aktuelle Management - Philosophien kritisch betrachtet. Management Zeitschrift, 3, 32-35.

Strumiłło, J. (2010). Koncepcja TQM, [w:] Koncepcje zarządzania, M. Czerska, A. Szpitter (red.), C.H. Beck, Warszawa.

Szymonik, A. (red.) (2013). Zarzadzanie zapasami i łańcuchem dostaw. Difin, Warszawa.

Śliwczyński, B. (2011). Controlling operacyjny łańcucha dostaw w zarządzaniu wartościa produktu. Wydawnictwo Uniwersytetu Ekonomicznego w Poznaniu, Poznań.

Tarasiewicz, R. (2014). Jak mierzyć efektywność tańcuchów dostaw. Oficyna Wydawnicza SGH, Warszawa.

Tolosi, P. \& Lajtha G. (2000). Toward improved benchmarking indicators. Telecommunications Policy, 24(4), pp. 347-357

Trocki, M. (2001). Outsourcing funkcji operacyjnych przedsiębiorstwa. Gospodarka Materiałowa i Logistyka, 2.

Walas-Trębacz, J. (2015). Projektowanie systemów zarządzania kryzysowego, [w:] Metodologia projektowania systemów organizacyjnych przedsiębiorstwa, A. Stabryła (red.), C.H. Beck, Warszawa.

Wawak, S. (2012). Analiza wartości, Encyklopedia Zarządzania, http://mfiles.pl/pl/index. php/Analiza_wartości (5.02.2015)

Womack, J. \& Jones, D. (1994). From Lean Production to Learn Enterprise. Harvard Business Review, March-April, pp. 164-165.

Zabawa, J. \& Krawczyk, R. (2006). Benchmarking procesów biznesowych w bankowości. Bank i Kredyt, 1.

Zimniewicz, K. (1999). Wspótczesne koncepcje i metody zarządzania. PWE, Warszawa. 